Jurnal Ekonomi dan Perbankan Syariah

Vol. 8. No.2, 0ktober 2020: 80-90, ISSN (cet): 2355-1755 | ISSN (online): 2579-6437

DOI: https://doi.org/10.46899/jeps.v8i2.229

\title{
THE EFFECT OF MUDHARABAH FINANCING ON THE PROFITABILITY OF ROA AND ROE OF SHARIA RURAL BANKS (BPRS) IN INDONESIA 2017-2018
}

\author{
Khansa Asy Syaffa ${ }^{1}$, Nur S. Buchori ${ }^{2}$, \\ Firmansyah $^{3}$
}

${ }^{1}$ SEBI: Email: khansyaffa@gmail.com

${ }^{2}$ SEBI Lecturer Email : buchori6632@gmail.com

${ }^{3}$ SEBI Lecturer Email : firms134@gmail.com

\begin{abstract}
The purpose of this research is to analyze The Influence of Mudharabah Financing as the dependent variable (X) To The Return On Asset (ROA) as independent variables $\left(\mathrm{Y}_{1}\right)$ and Return On Equity $(\mathrm{ROE})$ as independent variables $\left(\mathrm{Y}_{2}\right)$, of The Sharia Rural Banking (BPRS) in Indonesia in 2017-2018. This analysis used 106 BPRS that are made as a sample. The data sources used are secondary data sources from reports on financial publications of each Syariah Rural Banking at the OJK. This type of research is quantitative with Cross Section data method. The analysis technique used is the Eviews 10 for students. The results of this study indicate that Mudharabah Financing has no significant effect on the Ratio On Asset with a regression coefficient and a significance level of $0,16>0.05$. While Mudharabah Financing has no significant effect with the regression coefficient of 0,16 with a significance level $0,00<0.05$
\end{abstract}

Keywords: Mudharabah Financing, Ratio On Asset (ROA), Return On Equity (ROE), Syariah RuralBanking (BPRS).

\section{INTRODUCTION}

Sharia People's Financing Bank (BPRS) is one of the public trust institutions whose business activities are based on sharia principles. BPRS is required to always be able to carry out the mandate of the fund owners by channeling it to productive businesses in order to improve people's standard of living. In carrying out its business activities, BPRS must always uphold the principle of prudence and be able to apply sharia principles consistently, so as to create a healthy BPRS that is able to provide the best service to the community.(OJK, 2016)

When viewed from the composition of financing provided by BPRS based on the principle of contract, non-yield-based financing distribution murabahah dominates the yield-based financing (mudharabah and musyarakah). The following is a graph of the composition of financing

provided by the Sharia People's Financing Bank (BPRS) at the end of 2017-2018: (Fikriati, 2015) 
Jurnal Ekonomi dan Perbankan Syariah

Vol. 8. No.2, 0ktober 2020: 80-90, ISSN (cet): 2355-1755 | ISSN (online): 2579-6437

$\mathbf{8 1}$

Graph 1. 1 Composition of BPRS Financing Distribution in Indonesia Year $2017-2018$

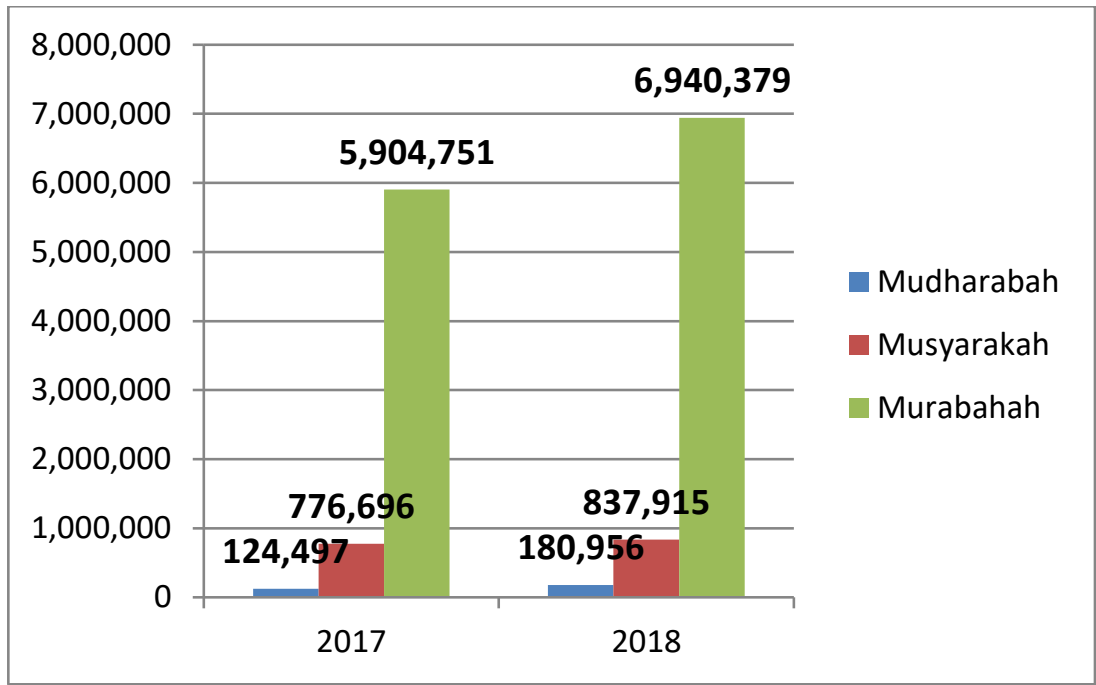

Source: Sharia Banking Statistics December 2017-2018, OJK processed

Based on chart 1.1 of the total financing disbursements conducted by BPRS in Indonesia is dominated by non-revenue-share financing (murabahah) in 2017 and 2018. While revenue-share-based financing (mudharabah and musyarakah) is still small, even the total revenue share financing does not reach half of the non-revenue-share financing (murabahah). This is not in line with Sharia Enterprise Theory.

The composition of the financing channeled as in graph 1.1 is unfortunate. This is because yield-based financing upholds the value and spirit of Islam more than buying and selling financing or others. One of the indicators of financial performance is that credit risk is explained by the ratio of mudharabah financing is a component that affects profitability.

The level of profitability is indicated by Return On Asset (ROA) and Return On Equity (ROE). This ratio is used to determine the ability of sharia commercial banks in managing their assets and capital to be disbursed in the form of mudharabah financing. (Mustofiyah, 2017).

The following table describes the total amount of Mudharabah, Return On Asset (ROA), Return Of Equity (ROE) financing entered in BPRS as a whole in Indonesia in 2017-2018: 
82 | Khansa Asy Syaffa, Nur S. Buchori, Firmansyah: The Effect 0f Mudharabah Financing 0n The Profitability of Roa And Roe 0f Sharia Rural Banks (BPRS) In Indonesia 2017-2018

Table 1. 1 Total Mudharabah Financing, ROA and ROE, compiled by BPRS in Indonesia in 2017-2018

\begin{tabular}{|l|l|l|l|}
\hline Years & Roa & ROE & $\begin{array}{l}\text { MUDHARABAH } \\
\text { FINANCING }\end{array}$ \\
\hline 2017 & $2,55 \%$ & $19,40 \%$ & 124,497 \\
\hline 2018 & $1,87 \%$ & $12,86 \%$ & 180,956 \\
\hline
\end{tabular}

Source: Sharia Banking Statistics December 2018, OJK processed

From table 1. 2, mudharabah's total financing increased in 2017 compared to 124,497 to 180,956 in 2018. Meanwhile, total ROA and ROE decreased in 2018 , namely ROA by $2.55 \%$ to $1.87 \%$. And ROE by $19.40 \%$ to $12.86 \%$. Based on this, researchers are interested in researching the relationship of mudharabah financing to the profitability of BPRS represented by roaand ROE.

Based on the background description of the problems raised, the problem of this research is formulated as follows: Whether Mudharabah Financingaffects Profitability (Return On Assets) on Sharia People's Credit Banks in Indonesia and also Whether Mudharabah Financing affects Profitability (Return On Equity)on Sharia People's Credit Banks in Indonesia.

The purpose of this research is to find out whether mudharabah financing affectsprofitability (Return On Assets)at Sharia People's Credit Banks in Indonesia. And also to find out if mudharabah financing affects profitability (Return On Equity)at the Sharia People's Credit Bank in Indonesia.

\section{LITERATURE REVIEW}

\subsection{SHARIA PEOPLE'S FINANCING BANK (BPRS)}

Bank Perkreditan Rakyat Syariah (BPRS) is one of the islamic banking financial institutions, whose operational pattern follows sharia principles or Islamic muamalah. BPRS was established based on Law No. 7 of 1992 on Banking and Government Regulation (PP) No. 72 of 1992 on Banks based on the Principle of Yield Share. In article 1 (point four) of Law No. 10 of 1998 concerning Amendment to Law No. 7 of 1992 on Banking, it is stated that Sharia People's Credit Bank (BPRS) is a bank that carries out business activities based on sharia principles which in its activities do not provide services in payment traffic (Hamid, 2008)

\subsection{FINANCING}

Financing is the provision of money or bills likened there to it, based on an agreement or agreement between the Bank and another party that requires the financed party to return the money or bill after a certain period of time in exchange or for the share of the proceeds (Kashmir, 2008) 
Jurnal Ekonomi dan Perbankan Syariah

Vol. 8. No.2, 0ktober 2020: 80-90, ISSN (cet): 2355-1755 | ISSN (online): 2579-6437

| 83

Based on Law No. 21 of 2008, financing is the provision of funds or bills that are equalized based on the agreement or agreement between sharia banks and other parties that require the financed party or given the facility to return the funds after a certain period of time in exchange for Ijarah, without reward, or profit share, financing in the form of:

1) Fruit-share transactions in the form of Mudharabah and Musyarakah

2) Rental transactions in the form of Ijarah or purchase leases in the form of Ijarah Muntahiya Bittamlik

3) Buying and selling transactions in the form of Murabahah, Salam, and Istishna' receivables

4) Loan transactions in the form of Qardh receivables.

\subsubsection{MUDHARABAH FINANCING}

Understanding Mudharabah Financing According to PSAK 105 mudharabah is a business cooperation agreement between two parties where the first party (shahibulmaal) provides all $(100 \%)$ capital, while the other party becomes the manager mudharib. Whereas According to (Suwiknyo, 2010)

Mudharabah is a business cooperation agreement between two parties in which the first party (the owner of the fund) provides all funds, while the second party (fund manager) acts as the manager. Based on the understanding of experts on the understanding of mudharabah above, it can be concluded that mudharabah is a cooperation agreement between two parties where the first party provides all capital and the other party becomes the manager. While the profit is divided according to the agreement specified in the contract.

Mudharabah objects include capital and business. The owner of the capital handed over his capital as an object mudharabah, while the executor of the business handed over his work as an object Mudharabah. The capital submitted can be in the form of money or goods detailed how much the money is worth. Meanwhile, the work submitted can be in the form of expertise in producing goods or services, managing skills, selling skills, and other skills or skills.

\subsection{Profitability}

According to the ratio of profitability is the ratio that indicates the effectiveness of creating profit. Profit shows how well companies make investment and financing decisions. Mandala manurung (2004: 209) argues profitability is demonstrating the company's ability to make a profit over a certain period. The profitability ratio of a bank is a tool to measure the level of business efficiency created by a company in question, besides profitability is defined as the ability of the bank in generating profit(HARJTO, 2011)(WIJAYA, 2001)(HASIBUAN, 2004).

\subsection{Ratio On Asset (ROA)}

According to K.R Subramanyam et al (2013) Return on Asset (ROA) is a ratio used to measure management's ability to obtain profit (profit after tax) resulting from the average total assets of the bank concerned. Profit aftertax is a net profit 
from operating activities after tax, while the average total asset is the average volume of business or assets.

According to Dwi Prastowo (2011) ROA is a ratio to measure the company's ability to utilize its assets to earn profit. This ratio is to measure the level of return on investment that has been made by the company using all funds (assets) it has. The formula for finding ROA is as follows:

ROA $=$ Profit After Tax X 100\%

Total Asset

\subsection{Return On Equity (ROE)}

ROE is one of the financial ratio analysis instruments used to measure the efficiency of a company's performance and the level of profitability of a company. Systematically ROE can be formulated as the ratio between net profit after tax to capital itself multiplied by $100 \%$ (Mustofiyah 2017).

The higher ROE demonstrates the company's ability to use its own capital to generate a high level of return for shareholders or investors. The amount of profit generated by the company is very influential on the small amount of Return On Equity (ROE) in a company. The higher the Return On Equity (ROE), the higher the profit that will be obtained by the company and the less problematic risk (Cashmere, 2010:114). The formula for finding ROA is as follows:

ROE $=$ Net Income After Tax

Shareholders' Equity

2.6 Hypothesis

$\mathrm{X}$ against $\mathrm{Y}$, With $\mathrm{X}$ is Mudharabah Financing. While $\mathrm{Y}_{1}$ is Return On Asset (ROA) and $\mathrm{Y}_{2}$ is Return On Equity (ROE).

$\mathrm{H}_{1}$ : Mudharabah Financing affects roa profitability at Sharia People's Credit Bank

$\mathrm{H}_{2}$ : Mudharabah Financing affects roe profitability at Sharia People's Credit Bank

\section{RESEARCH METHODOLOGY}

This type of research is quantitative. Kuntitatif research is research that emphasizes the testing of theories - theories through variables - research variables in the form of numbers and through data analysis using statistics or mathematical modeling. A population is a group of individuals - individuals or objects that have certain standards of traits that have been set before. Samples are part of the number and characteristics of the population. The samples used in this study are all BPRS in Indonesia in the period 2017-2018.

Data collection techniques are carried out through Literature studies in the form of data collection by reading books from several works of literature, references, reports - financial statements, and materials - materials related to this 
research. Download data - related data through the website as well as information related to this research through search engines www.google.com

The data used in this study is secondary data. Secondary data is data obtained from the second source (not the first person. not the original) that has the information or data. The data used in this research comes from the publication report of Bank Indonesia (BI) and the Financial Services Authority (OJK), namely SPS (Sharia Banking Statistics). Besides, financial report data from The Sharia People's Financing Bank in Indonesia has been published on the OJK website. Data is taken manually and individually from the web report publication BPRS, OJK. The data is taken as much as the data listed in the BPRS publication report which is then filtered according to the needs of variables. Macro-economic data is also taken from other supporting sources in the form of necessary journals and other sources that can be used in this research (Idrus, 2009).

Following the title of the study selected by the author, namely the Influence of Mudharabah Financing on Profitabiliutas ROA and ROE, the author grouped the variables used in this study into dependent variables (Y)and Independent variables(X). The explanation is as follows: Variable bound (Y) is a variable that is affected or that becomes a result, because of the existence of free variables. In this study, the independent variables studied were (Sugiono, 2016)Profitability in BPRSIndonesia. Variable Bebas (IndependentVariable), Variable free $(\mathrm{X})$ variable is often referred to as variable stimulus, predictor, antecedent. In Indonesian, it is often called variable free. Free variables are variables that affect or cause changes or the onset of dependent variables (bound) (Sugiyono, 2016). In this study the independent variables studied were MudharabahFinancing.

In quantitative research, dependent variables are represented by letters( $(Y)$, in this research bound variables that will be measured profitability in BPRS Indonesia, which consists of; Profitability of ROA $\left(\mathrm{X}_{1}\right.$ ): Return On Asset (ROA) is the profitability of BPRS compared to assets owned, both current and non-current assets. Measured by dividing profitability with Assets. Profitability $\operatorname{ROE}\left(\mathrm{X}_{2}\right)$ : Return On Equity (ROE) is the profitability of BPRS generated on assets owned. Measured by dividing profitability by equities. As for the free variable (independent) symbolized letter $(\mathrm{X})$,. In this research $\mathrm{X}=$

Mudharabah Financing is measured by sorting mudharabah financing from the total financing in the Shari'ah People's Credit Bank in Indonesia.

The analysis method used is multiple linear regression analysis using panel data analysis. Panel data regression analysis is regression analysis with a data structure which is panel data. Generally, the presumption of parameters in regression analysis with cross-section data is done using the least-squares method guessing or called Ordinary Least Square $(O L S)$ by using Eviews 10 for students. 
86 | Khansa Asy Syaffa, Nur S. Buchori, Firmansyah: The Effect 0f Mudharabah Financing 0n The Profitability of Roa And Roe 0f Sharia Rural Banks (BPRS) In Indonesia 2017-2018

\section{DISCUSSION}

Based on the proposed hypothesis, the model was used to see the influence of Mudharaah Financing on ROA and ROE Profitability. The regression equation formed is as follows:

And $_{1} \mathrm{x}$ a + bx

And $_{2} \mathrm{a}+\mathrm{bx}$

Description:

$\mathrm{a}=$ Constanta

$\beta=\mathrm{P} \times 1$ sized vector is the estimated result parameter

$\mathrm{Y}_{1}=$ Profitabilitas Return On Asset (ROA)

$\mathrm{Y}_{2}=$ Profitabilitas Return On Equity (ROE)

$\mathrm{x}=$ Mudharabah Financing

The results of multiple linear regression analysis in the eviews program obtained results as shown in the table with data that has been transformed into logarithm form as follows:

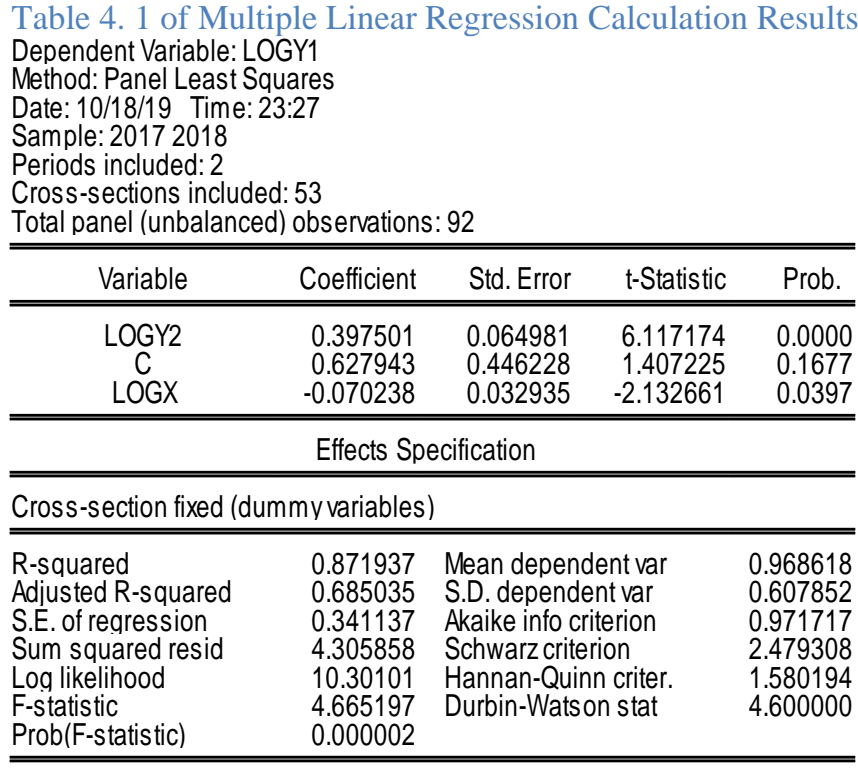

From table 4.6 above, it can be compiled multiple linear regression equations are as follows:

$\mathrm{And}_{1}(0.45) \times 0.16+0.62 .0 .03$

$\mathrm{And}_{2}(0.00) \times 0.16+0.62 .0 .03$

Based on the results of the data processed above, the results of the regression coefficient can be interpreted as follows:

a. Constant value of 0.62 . This means that if a free variable is considered constant or does not change or a free variable $=0$ then, the bound variable value will be 0.62 . Constant value of 0.62 multiple linear results, here constants have a positive effect. So ROA has a positive value towards mudharabah financing. If the 
Jurnal Ekonomi dan Perbankan Syariah

Vol. 8. No.2, 0ktober 2020: 80-90, ISSN (cet): 2355-1755 | ISSN (online): 2579-6437

| 87

ROA increases by 1 percent then mudharabah financing will increase by 0.62 .

b. Coefficient value $b=0.16$. This means that if ROA $\left(Y_{1)}\right.$ and ROE $\left(\mathrm{Y}_{2}\right.$ change by 1 percent, then the composition of mudharabah financing changes by 0.16 percent the assumption of other variables remains. Roa and ROE coefficients are positive, roa and ROE have a positive value towards mudharabah financing. if ROA and ROE increase by 1 percent then mudharabah financing will increase by 1 0.16 percent.

Table 4. 2 Analysis Results

Dependent Variable: LOGY1

Method: Panel Least Squares

Date: 10/18/19 Time:23:27

Sample: 20172018

Periods included: 2

Cross-sections included: 53

Total panel (unbalanced) observations: 92

\begin{tabular}{ccccc}
\hline \hline Variable & Coefficient & Std. Error & t-Statistic & Prob. \\
\hline \hline LOGY2 & 0.397501 & 0.064981 & 6.117174 & 0.0000 \\
LOGX & 0.627943 & 0.446228 & 1.407225 & 0.1677 \\
& -0.070238 & 0.032935 & -2.132661 & 0.0397 \\
\hline \multicolumn{5}{c}{ Effects Specification } \\
\hline \hline Cross-section fixed (dummy variables) \\
\hline \hline R-squared & 0.871937 & Mean dependent var & 0.968618 \\
Adjusted R-squared & 0.685035 & S.D. dependent var & 0.607852 \\
S.E. of regression & 0.341137 & Akaike info criterion & 0.971717 \\
Sum squared resid & 4.305858 & Schwarz criterion & 2.479308 \\
Log likelihood & 10.30101 & Hannan-Quinn criter. & 1.580194 \\
F-statistic & 4.665197 & Durbin-Watson stat & 4.600000 \\
Prob(F-statistic) & 0.000002 & & \\
\hline \hline
\end{tabular}

Based on the results of the data processed using Hausman test above, it can be seen that;

a. Mudharabah financing is said to have a significant influence if the probability value is $<0.05$. Based on the analysis, Mudharabah Financing has significantly no effect on Profitability Return On Asset (ROA), because the probability value of ROA $>0.05$. That's 0.16 . So it can be concluded that $\mathrm{H}_{0}$ is accepted and $\mathrm{H}_{1}$ is rejected.

b. Mudharabah financing is said to have a signing effect when the probability value is $<0.05$. Based on the analysis, Mudharabah Financing significantly influences Profitability Return On Equity (ROE), due to the profitability value of $\mathrm{ROE}<0.05$. That's 0.00 . So it can be concluded that $\mathrm{H}_{0}$ is rejected and $\mathrm{H}_{1}$ is accepted.

This is in line with profitability with the Return On Equity (ROE) ratio used to determine the ability of sharia commercial banks in managing their 
capital to be channeled in the form of mudharabah financing. (Mustofiyah 2017) . So, the greater the amount of ROE, the more it will affect the amount of financing channeled.

Based on the results of multiple regression calculations in table 4.1 it can be known that changes in ROA variable rates have a positive relationship to the composition of mudharabah financing at the Shari'ah People's Financing Bank (BPRS) in Indonesia in the period 2017-2018. However, if seen from the significance of $t$, does not have a significant effect because the value of $t$ significance is greater than 0.05Thing indicates that if there is an increase in ROA then mudharabah financing at the Sharia People's Financing Bank (BPRS) in Indonesia will increase as well.

The results of the above study explain that the Sharia People's Financing Bank in Indonesia has not been able to perform its intermediation function properly. Roa variables can not affect mudharabah financing with a composition greater than ROE. Therefore, to obtain more maximum results in channeling ROA to mudharabah financing because ROA is more influential on the profit (profit) of The People's Credit Bank Syari'ah. The higher the ROA value, the greater the profit on the Shari'ah People's Credit Bank, and the financing influences the profits of Shari'ah RURAL BANKS.

Based on the results of multiple regression calculations in table 4.1 above, it can be known that ROE also has a positive relationship to mudharabah financing at the Mudharabah Financing Bank at the Sharia People's Financing Bank (BPRS) in Indonesia in the period 2017-2018. Profitability with Return On Equity (ROE) ratio used to determine the ability of sharia commercial banks in managing their capital to be channeled in the form of mudharabah financing. (Mustofiyah 2017) . So, the greater the amount of ROE, the more it will affect the amount of financing channeled.

\section{CONCLUSION}

Based on the results of data processing from the research entitled "The Effect of Mudharabah Financing on the Profitability of ROA and ROE of Sharia People's Financing Bank (BPRS) in Indonesia in the period 2017-2018, there are several conclusions as follows:

1. Partially

a. Mudharabah Financing composition has no significant effect on the profitability of Return On Assets (ROA) atSharia People's Financing Banks in Indonesia in the period 2017-2018. Roa regression coefficient value of 0.16 means that each increase in ROA composition changes by 1 percent, so the composition of mudharabah financing changes by 0.16 percent of other fixed variable assumptions. Profitability Value 0.16 Because the significance level is greater than 0.05 then partially roa changes cannot affect mudharabah financing composition positively and significantly. The first hypothesis of $\mathrm{H}_{0}$ research is mudharabah financing does not have a positive influence on Profitability Return On Asset (ROA). Thus partially changes in Mudharabah Financing can not 
affect roa profitability positively and significantly in otherwords $\mathrm{H}_{0}$ diterima and $\mathrm{H}_{1}$ ditolak. The results of this study explain that the Sharia People's Financing Bank in Indonesia has not been able to perform its intermediation function properly in the period 2017-2018. This can also be caused because roa is more influential on the profit (profit) of The People's Credit Bank Shari'ah. Because the higher the ROA value, the greater the profit on the Shari'ah People's Credit Bank and the financing has an influence on the profits of Sharia Rural Banks.

b. Roe value significantly affects mudharabah financing at Sharia People's Financing Bank in Indonesia in the period 2017-2018. Statistical t value of 0.00 . That means $\mathrm{H}_{0}$ is accepted and $\mathrm{H}_{1}$ is rejected. The coefficient value of ROE is 0.16 . That is if ROE as $\mathrm{Y}_{2}$ changes by 1 percent then the composition of mudharabah financing changes by 0.16 percent. The assumption of the other variable is fixed. The results of this study show that the small amount of ROE that has been realized by BPRS depends on the size of roe. This is because profitability with return on equity (ROE) ratio is used to determine the ability of sharia commercial banks in managing their capital to be channeled in the form of mudharabah financing. (Mustofiyah 2017). Thus, the greater the amount of ROA, the more it will affect the amount of financing channeled.

2. It can be known simultaneously by analyzing the F Test. F test can be done by comparing $\mathrm{F}$ calculate with $\mathrm{F}$ Table, if $\mathrm{F}$ calculates> from $\mathrm{F}$ table, then Ho rejected $\mathrm{Ha}$ accepted and can be said simultaneuos. F calculate (F statistic) on analysis Eviews 10 for student is 4.66. While the large F table on eviews can be calculated by searching for N1 and N2. N1= The sum of all variables -1 , i.e. $3-1=2$. N2 $=$ Number of samples - number of variables, i.e. $106-3=103$. So the big dots N1 and N2 on the F table yes it's 3.08 (judging from the PDF table F 0.05). It can be concluded that F calculate $>\mathrm{F}$ table is $4.66>3.08$. And can be said simultaneously.

\section{REFERENCES}

Hamid, A. R. (2008, December 20).

Harjito, M. d. (2011). https://media.neliti.com s a good https://media.neliti.com. things. 74.

Hasibuan, S. (2004). eprint.perbanas.ac.id. 104.

Idrus, M. (2009). Social Research Method. Jakarta: Erlangga.

Janwari, D. d. (2012, December 7). https://www.slideshare.net.

Cashmere. (2008). Understanding of financing in general. things. 96.

Mustofiyah (2017), The Effect of Mudharabah Financing on Return On Equity (Roe) andNon Performing Financing (NPF) as Intervening Variables in Sharia Commercial Banks (Period 2011-2015)

OJK (2016). Sharia People's Financing Bank.Jakarta.

Sugiono, I'm sorry. (2016 repository.unpas.ac.id). things. 59.

Wijaya, D. (2001). repository.umy.ac.id. 119. 
90 | Khansa Asy Syaffa, Nur S. Buchori, Firmansyah: The Effect 0f Mudharabah Financing 0n The Profitability of Roa And Roe 0f Sharia Rural Banks (BPRS) In Indonesia 2017-2018

Wirman, what's going on? (2017). Factors Affecting Profit Share Based Financing Volume and BOPO Ratio in Sharia Banking. Journal of Business and Accounting(Vol. 19, No. 1).

Yuliani (2015). Www. kompasiana.com, Why do you prefer mudharabah financing.

Zahro (2018). Analysis of the Influence of Musyarakah, Mudharabah and Murabahah Financing on the Profitability of Sharia People's Financing Banks (Bprs) in Indonesia period January 2015 - December 2017

Zuhaeri, W. (2014). Analysis of the Influence of FDR, NPF, Profit Share Level, Service Quality and Attributes of Islamic Products on Mudharabah Financing Level at Sharia Commercial Banks in Semarang. Semarang: Economica. 